\title{
Comparison of three molecular methods for typing and subtyping pathogenic Yersinia enterocolitica strains
}

\author{
I. ITEMAN, A. GUIYOULE and E. CARNIEL* \\ Yersinia National Reference Laboratory and WHO Collaborating Centre, Institut Pasteur, 75724 Paris Cedex 15, \\ France
}

\begin{abstract}
The efficiency of pulsed-field gel electrophoresis (PFGE), ribotyping and restriction enzyme analysis of the virulence plasmid (REAP) for typing and subtyping strains of Yersinia enterocolitica was compared. All three techniques gave concordant results, and the strains studied could be separated into three distinct clusters: (1) heterogeneous strains of biotype 1A and serotype 05 (1A/O5); (2) one 3/03 strain and all 2/09 strains; and (3) all 4/O3, 2/O5 and two 3/O3 strains. Within cluster 3, the $2 / 05$ and 3/03 strains were related more closely to each other than to the 4/O3 isolates. With ribotyping, PFGE and phage-typing, the 4/O3 isolates were subdivided into two homogeneous groups, corresponding to strains of phage type $\mathrm{IX}_{\mathrm{b}}$ and strains of other phage types, respectively. Similarly, ribotyping and PFGE subdivided the 2/09 strains into two conserved groups (I and II), but REAP gave a different subdivision and identified a new REAP pattern. (P3). The three techniques confirmed the clear distinction between the heterogeneous group of non-pathogenic 1A/O5 strains and the well conserved group of pathogenic 2/05 strains. Additional plasmids were identified in some 3/03 strains. Combined, the results indicated that REAP (with EcoRI) and ribotyping (with EcoRV) are valuable alternatives to bioserotype determination, and PFGE is the most suitable technique for epidemiological tracing.
\end{abstract}

\section{Introduction}

Yersinia enterocolitica is an enteropathogenic gramnegative bacterium that is distributed widely and can cause mild abdominal pain, fever and diarrhoea. The species is divided into six biotypes [1]. Biotype 1A comprises avirulent strains, and biotypes $1 \mathrm{~B}$ and 2-5 include strains that are potentially pathogenic for man and animals. Among the pathogenic strains of $Y$. enterocolitica, those of biotype $1 \mathrm{~B}$ are limited to geographical areas such as the USA and Japan [2]. Those of biotype 5, which are rare, are isolated essentially from hares. The most widespread pathogenic strains of $Y$. enterocolitica belong to biotypes 4, 2 and, less frequently, 3 . These strains cause infections in man, limited usually to mild diarrhoea, abdominal pain and fever.

An O-antigen serotyping scheme has been used to subdivide strains of $Y$. enterocolitica. More than 50 serotypes have been described to date [3], but serotyping does not differentiate pathogenic from

Received 5 Oct. 1995; accepted 27 Nov. 1995

${ }^{*}$ Corresponding author: Dr E. Carniel. non-pathogenic isolates definitively. An accurate designation of pathogenic $Y$. enterocolitica strains needs to take into account both the biotype and the serotype of a strain. However, the two traits are linked closely: biotype 4 is associated with serotype O3 (4/ O3); biotype 2 with serotype 09 and, less frequently, O5; and biotype 3 with serotypes $\mathrm{O} 3$ and $\mathrm{O} 5$. Therefore, the number of bioserotypes characterising the most common strains of $Y$. enterocolitica involved in infections of man is limited. Other phenotypic markers such as phage-typing [4] and H-antigen serotyping [5] are helpful in subdividing the strains, but are performed only by a few reference laboratories.

Several molecular methods have been applied to $Y$. enterocolitica, but there has been no previous study comparing the discriminatory power of ribotyping, restriction enzyme analysis of the virulence plasmid (REAP) and pulsed-field gel electrophoresis (PFGE) for typing (i.e., identifying the bioserotype) and subtyping (i.e., subdividing strains of the same bioserotype) pathogenic $Y$. enterocolitica. To achieve this goal, strains of $Y$. enterocolitica analysed previously by PFGE [6] were characterised in this study by ribotyping and REAP. 


\section{Materials and methods}

\section{Bacterial strains and growth conditions}

The 63 strains of $Y$. enterocolitica studied were from the strain collection of the French Yersinia Reference Laboratory and WHO Collaborating Centre (Institut Pasteur, Paris). The phenotypic characteristics used commonly to type $Y$. enterocolitica strains are their biotype (arabic number), serotype (number preceded by ' $\mathrm{O}$ '), and phage type (roman number). For example, a strain of biotype 4 , serotype $\mathrm{O} 3$ and phage type VIII is designated 4/O3/VIII. Biotyping, serotyping and phage typing were performed at the Institut Pasteur reference laboratory. The strains were used in a previous study evaluating the efficiency of PFGE for subtyping $Y$. enterocolitica strains [6]. Their relevant characteristics are described in Tables 1-4. Strains IP 22464, IP 22981, IP 21100 and IP 885 of serotype O5 were included previously in biotype 3 [6] because they did not produce indole in a classical urea-indole medium (Sanofi Diagnostics Pasteur, Marnes la Coquette, France). Subsequent examination of the in-vitro sensitivity to ticarcillin of those four strains and their indole production in a more sensitive medium (Bacto tryptone $1 \% \mathrm{w} / \mathrm{v}$, L-tryptophan $3 \% \mathrm{w} / \mathrm{v}$ in peptone broth) revealed that these strains were of biotype 2 (G. Wauters, personal communication). For plasmid or genomic DNA extractions, all $Y$. enterocolitica strains were grown overnight at $30^{\circ} \mathrm{C}$ with shaking in peptone broth.

\section{Pulsed-field gel electrophoresis}

Preparation of agarose plugs, digestion of DNA with Not I, and conditions for PFGE with the zero-integrated-field electrophoresis (ZIFE) technique were as described previously [6]. The term 'pulsotype' refers to a genomic PFGE restriction profile obtained with a given restriction endonuclease in a precise range of fragment sizes [6]. In this study, 'pulsotype' designates the NotI genomic restriction profile obtained with the 150-200-kb ROM card. Any difference between two profiles, even a single band, was sufficient to distinguish two pulsotypes. A superscript letter was used to distinguish each pulsotype within strains of the same biotype (e.g., $4^{\mathrm{A}}$ ).

\section{REAP}

Plasmid extraction was performed according to the method of Birnboim and Doly [7]. Plasmid DNA was digested overnight with either EcoRI or Bam HI and then analysed by electrophoresis on agarose $0.8 \% \mathrm{w} / \mathrm{v}$ gels. The EcoRI and Bam HI restriction profiles were combined to generate a REAP profile (see Tables 1-4).

\section{Ribotyping}

Genomic DNA was digested with EcoRI and EcoRV, chosen because of previous results obtained with $Y$. pestis [8]. For $Y$. enterocolitica 4/O3 strains, NciI was also used. The molecular size standards used to determine the sizes of the DNA fragments comprised EcoRI-digested genomic DNA of Xenorhabdus 278 (Fig. 2). A 16S + 23S rRNA probe [9] labelled with acetylaminofluorene was used in this study. Hybridisation and immuno-enzymatic detection of hybridising fragments were performed as described previously [8]. Ribotypes were designated by combining the hybridisation profiles obtained after digestion with EcoRI and EcoRV (see Tables 1-4).

\section{Results and discussion}

\section{Subdivision of 4/O3 strains of $Y$. enterocolitica into two clusters displaying high genomic homogeneity}

PFGE analysis of the $204 / \mathrm{O} 3$ strains of $Y$. enterocolitica listed in Table 1 subdivided them previously into 11 pulsotypes [6]. Although not identical, some profiles exhibited only minor differences and the overall homogeneity of the profiles was high.

At initial isolation, most pathogenic strains of $Y$. enterocolitica harbour a $70-\mathrm{kb}$ virulence plasmid (pYV) which is lost rapidly after subculture at $37^{\circ} \mathrm{C}$ [10]. Of the $204 / \mathrm{O} 3$ strains studied, only nine harboured a pYV plasmid (Table 1). Restriction analysis of these plasmids revealed the same EcoRI and Bam HI profiles (Fig. 1), which were identical to those of other 4/O3 strains described [11-13]. Although two additional REAP profiles among 4/O3 strains have been reported subsequently [14], these new profiles were confined to three Scandinavian isolates. The present results indicate that the pYV plasmid of the 4/O3 strains is highly conserved and suggest that REAP is not an efficient method for subtyping $4 / \mathrm{O} 3$ isolates.

All 20 4/O3 strains had the same EcoRI and EcoRV ribopatterns (Fig. 2 and Table 1), and hence the same ribotype. Picard-Pasquier et al. [15] also found that the EcoRI ribotypes of two biotype 4 strains were identical. Two laboratories have reported that analysis of $\mathrm{NCi}$ I fingerprints was efficient in subtyping 4/O3 strains of $Y$. enterocolitica $[16,17]$. When the genomic DNA of the 20 strains listed in Table 1 was digested with $\mathrm{Nci}$ I and hybridised with the 16S + 23S RNA probe, two $\mathrm{Nci}$ I ribopatterns ( $\mathrm{N} 1$ and $\mathrm{N} 2$; Fig. 3) were shared by two (strains IP 4244 and IP 22276) and 18 isolates, respectively. The two N1 pattern isolates were of phage type $\mathrm{IX}_{\mathrm{b}}$, a phage type found essentially in Canada, USA, Australia and New Zealand [18, 19]. These data are in agreement with those of Blumberg et al. [17] who also found an association between their Nci I ribopattern I and phage type $\mathrm{IX}_{\mathrm{b}}$. These two strains also displayed very similar PFGE profiles [6]. Furthermore, 4/O3/IX $\mathrm{b}$ strains exhibit a peculiar $\beta$-lactamase profile in that while most $4 / 03$ strains 
Table 1. Characteristics of $4 / \mathrm{O} 3$ strains of $Y$. enterocolitica

\begin{tabular}{|c|c|c|c|c|c|c|c|}
\hline $\begin{array}{l}\text { Strain } \\
\text { no. }\end{array}$ & $\begin{array}{l}\text { Phage } \\
\text { type }\end{array}$ & Origin & Source & $\begin{array}{l}\text { Country of } \\
\text { origin }\end{array}$ & Pulsotype* & $\begin{array}{l}\mathrm{REAP}^{\dagger} \\
(E \operatorname{Eco} \mathrm{RI} / \operatorname{Bam} \mathrm{HI})\end{array}$ & $\begin{array}{l}\text { Ribotype } \\
(E c o \text { RI/EcoRV })\end{array}$ \\
\hline IP 4214 & VIII & Man & Stool & Greece & $4^{A}$ & Pl (1/1) & $\mathrm{R} 1(\mathrm{a} / \mathrm{a})$ \\
\hline IP 4302 & VIII & Man & $\mathrm{UN}$ & Germany & $4^{A}$ & $\xi$ & R1 (a/a) \\
\hline IP 6041 & VIII & Man & Stool & France & $4^{A}$ & Pl (1/1) & $\mathrm{Rl}(\mathrm{a} / \mathrm{a})$ \\
\hline IP 7011 & VIII & Man & Blood & France & $4^{\mathrm{A}}$ & $\xi$ & $\mathrm{Rl}(\mathrm{a} / \mathrm{a})$ \\
\hline IP 7596 & VIII & Man & Stool & France & $4^{A}$ & P1 (1/1) & $\mathrm{R} 1 \quad(\mathrm{a} / \mathrm{a})$ \\
\hline IP 8492 & VIII & Man & Stool & Spain & $4^{A}$ & $\xi$ & $\mathrm{R} 1 \quad(\mathrm{a} / \mathrm{a})$ \\
\hline IP 8896 & VIII & Man & UN & Italy & $4^{\mathrm{A}}$ & $\mathrm{P} 1(1 / 1)$ & $\mathrm{R} 1 \quad(\mathrm{a} / \mathrm{a})$ \\
\hline IP 8944 & VIII & Man & Blood & Greece & $4^{\mathrm{A}}$ & P1 (1/1) & $\mathrm{R} 1$ (a/a) \\
\hline IP 22435 & IXa & Man & UN & France & $4^{\mathrm{A}}$ & $\xi$ & $\mathrm{R} 1$ (a/a) \\
\hline IP 23111 & VIII & Man & Stool & France & $4^{\mathrm{A}}$ & $\xi$ & $\mathrm{R} 1 \quad(\mathrm{a} / \mathrm{a})$ \\
\hline IP 6908 & VIII & Man & Stool & Spain & $4^{\mathrm{B}}$ & $\xi$ & $\mathrm{Rl}(\mathrm{a} / \mathrm{a})$ \\
\hline IP 864 & VIII & Man & Stool & Belgium & $4^{\mathrm{C}}$ & P1 (1/1) & $\mathrm{R} 1(\mathrm{a} / \mathrm{a})$ \\
\hline IP 22785 & VIII & Man & Stool & Italy & $4^{\mathrm{D}}$ & P1 (1/1) & $\mathrm{R} 1$ (a/a) \\
\hline IP 4424 & VIII & Pig & Tongue & Belgium & $4^{\mathrm{E}}$ & P1 (1/1) & $\mathrm{R} 1$ (a/a) \\
\hline IP 7841 & $\mathrm{IXa}$ & Man & Stool & Africa & $4^{F}$ & P1 (1/1) & $\mathrm{Rl}(\mathrm{a} / \mathrm{a})$ \\
\hline IP 10393 & VIII & Man & Stool & France & $4^{\mathrm{G}}$ & $\xi$ & $\mathrm{R} 1(\mathrm{a} / \mathrm{a})$ \\
\hline IP 4244 & $\mathrm{IXb}$ & Man & Stool & Canada & $4^{\mathrm{H}}$ & $\vec{\xi}$ & $\mathrm{R} 1(\mathrm{a} / \mathrm{a})$ \\
\hline IP 4439 & VIII & Pig & Tongue & Holland & $4^{I}$ & $\xi$ & $\mathrm{R} 1 \quad(\mathrm{a} / \mathrm{a})$ \\
\hline IP 22701 & XI & Man & UN & Chile & $4^{\mathrm{J}}$ & $\vec{\xi}$ & $\mathrm{Rl}(\mathrm{a} / \mathrm{a})$ \\
\hline IP 22276 & $\mathrm{IXb}$ & Man & Stool & Australia & $4^{K}$ & $\xi$ & $\mathrm{R} 1(\mathrm{a} / \mathrm{a})$ \\
\hline
\end{tabular}

$\mathrm{UN}$, unknown.

${ }^{*}$ Not I restriction pattern as described previously [6]

${ }^{\dagger}$ Combination of the EcoRI and Bam HI patterns.

${ }^{\ddagger}$ Combination of the EcoRI and EcoRV patterns.

$\xi N o$ pYV plasmid present in the strain.

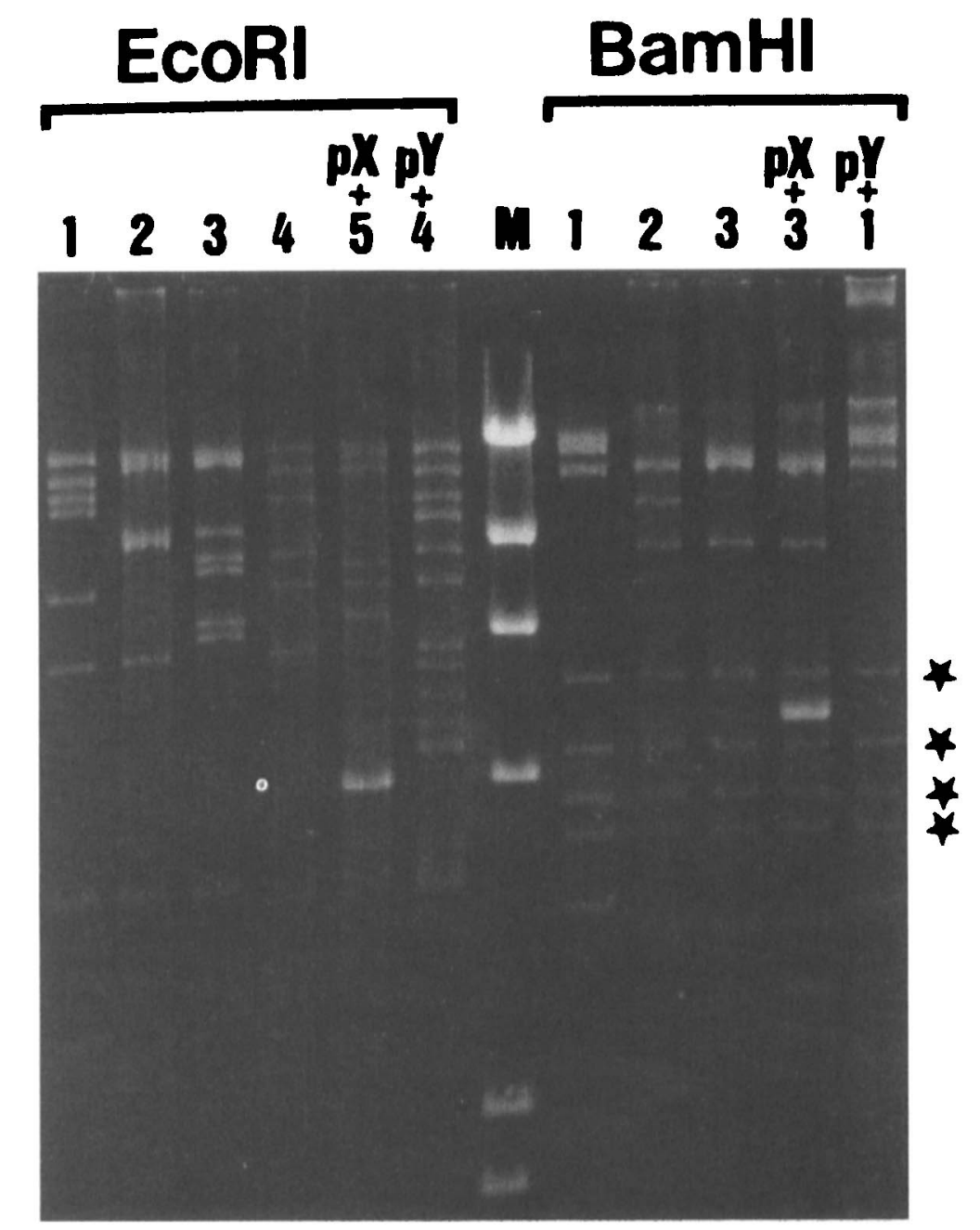

Fig. 1. Examples of EcoRI and Bam HI restriction profiles (REAP) of pYV plasmids from pathogenic strains of $Y$. enterocolitica. Track numbers correspond to the different plasmid profiles listed in the Tables. Tracks $\mathrm{pX}$ and $\mathrm{pY}$ contain DNA of additional plasmids found in strains IP 22227 and IP 23446, respectively. M, lambda DNA digested with HindIII (fragments of 23.1, 9.4, 6.5, 4.3, 2.3 and $2.0 \mathrm{~kb}$ ). Asterisks indicate conserved Bam HI restriction fragments. 
A $\quad$ B

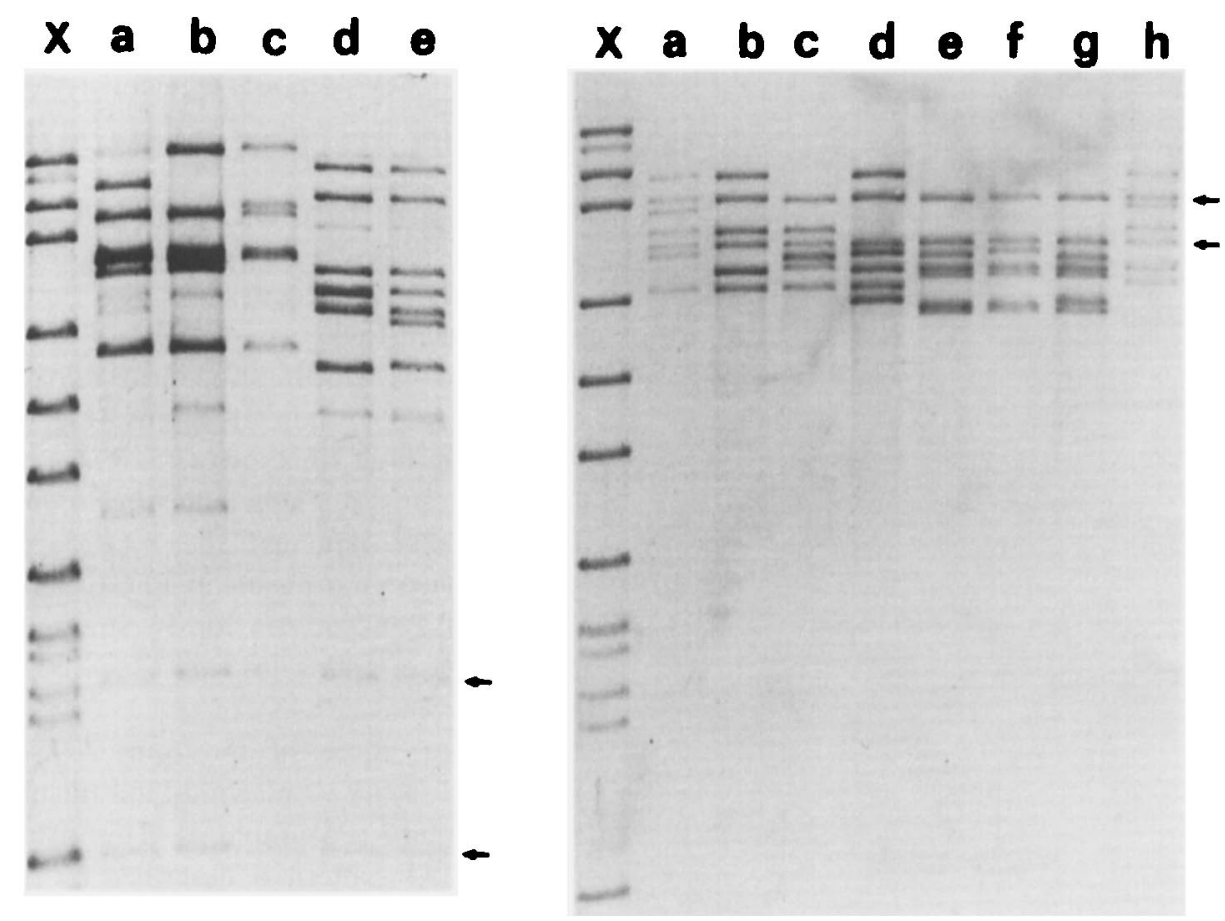

Fig. 2. Examples of ribopatterns obtained following digestion with: A, EcoRI; B, EcoRV. Track letters correspond to the different ribopatterns listed in the Tables. X, Xenorhabdus 278 DNA digested with EcoRI (fragments of 13.0, 11.6, $10.1,8.5,5.8,4.6,3.8,2.9,2.5,2.4,2.2,2.1$ and $1.5 \mathrm{~kb}$ ). Arrows indicate conserved ribopattern fragments.

synthesise two types of $\beta$-lactamase (a penicillinase and a cephalosporinase), phage type $\mathrm{IX}_{\mathrm{b}}$ strains do not synthesise the cephalosporinase [19]. Thus, although analysis of electrophoretic protein polymorphisms did not differentiate strains of phage types VIII and IX [20], analysis by PFGE, ribotyping, phage typing and $\beta$-lactamase pattern all indicated that the $4 / \mathrm{O} 3 / \mathrm{IX}_{\mathrm{b}} Y$. enterocolitica strains form a cluster. Different phage types (VIII, IX $\mathrm{X}_{\mathrm{a}}$ and XI) were found among the 18 strains with the $\mathrm{N} 2$ ribopattern, indicating that phagetyping was more efficient than ribotyping for subdividing these isolates.

Therefore, the overall results suggest that the genome of the 4/O3 strains of $Y$. enterocolitica has diverged into two groups represented by strains of phage type $\mathrm{IX}_{\mathrm{b}}$ and strains of other phage types, respectively. Within each group, a high level of genomic homogeneity was observed. The fact that the strains were isolated from different hosts, sources and countries (Table 1) supports a hypothesis of geographical spread of an original 4/O3 clone.

\section{Division of $2 / O 9 / X_{3}$ strains of $Y$. enterocolitica into two main genomic groups}

Of the $202 / 09 / \mathrm{X}_{3}$ strains of $Y$. enterocolitica studied, 11 harboured a pYV plasmid. Two different EcoRI and Bam HI plasmid profiles were obtained (Fig. 1 and Table 2). The two Bam HI profiles were almost identical while the two EcoRI profiles had very few similarities. Nevertheless, a strict correlation was observed between the EcoRI and Bam HI profiles, and restriction of the $\mathrm{pYV}$ plasmid therefore allowed subdivision of the $2 / \mathrm{O} 9 / \mathrm{X}_{3}$ strains into two REAP patterns: P2 (six strains) and P3 (five strains). The P2 pattern was identical to that described for different $Y$. enterocolitica $\mathrm{O} 9$ strains of world-wide origin by other laboratories [11-14], but almost half the $2 / 09 / \mathrm{X}_{3}$ isolates in the present study showed the previously undescribed P3 pattern. There was no correlation between the geographical origin or source of the strains and their REAP patterns. Analysis of the same $2 / \mathrm{O} 9 / \mathrm{X}_{3}$ strains by PFGE also demonstrated two subgroups [6], although these were completely different from those derived from the REAP profiles (Table 2). Furthermore, in two cases, strains that displayed the same pulsotype $\left(2^{\mathrm{D}}\right.$ or $\left.2^{\mathrm{G}}\right)$ had two different REAP patterns (P2 and P3; Table 2).

Ribotyping of the $202 / \mathrm{O} 9 / \mathrm{X}_{3}$ strains identified two $E c o$ RI (b and c) and three EcoRV (b, c and d) ribopatterns, resulting in three ribotypes: $\mathrm{R} 2$ (15 strains; R3 (one strain); and R4 (four strains) (Fig. 2 and Table 2). With the exception of the ribotype R3 strain, there was a strict correlation between EcoRI and EcoRV ribopatterns c, and between EcoRI and EcoRV ribopatterns d. Few data concerning the ribotypes of $Y$. enterocolitica $2 / 09 / \mathrm{X}_{3}$ strains have been published. Since the ribopatterns of only six strains have been reported previously [15-17], it is difficult to draw any conclusion concerning the diversity of the ribotypes in this group of strains. The data indicate that the $2 / 09 / \mathrm{X}_{3}$ strains have two 


\section{$X$ N1 N2}

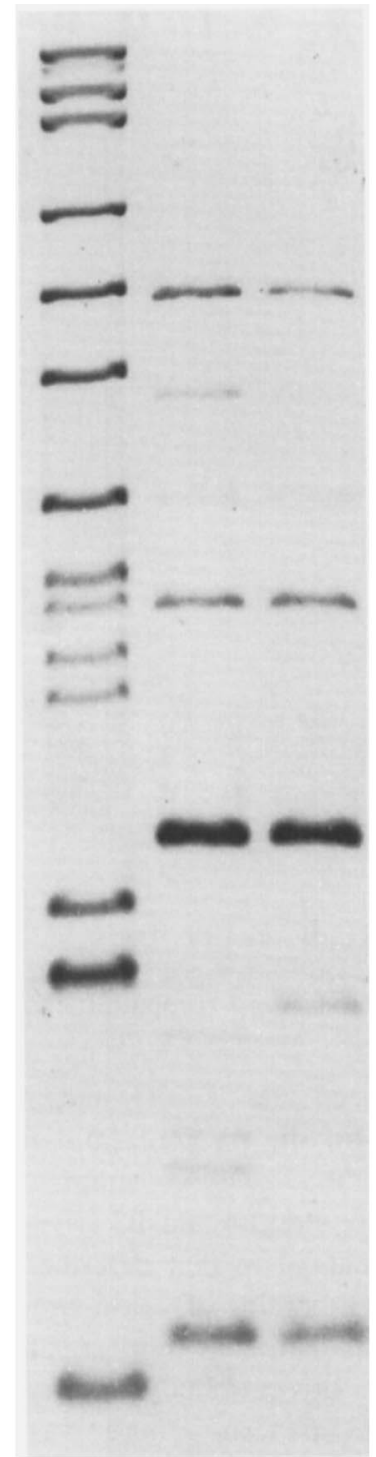

Fig. 3. Examples of the $\mathrm{N} 1$ and $\mathrm{N} 2$ ribopatterns found amongst $4 / \mathrm{O} 3$ strains of $Y$. enterocolitica following digestion of genomic DNA with NciI. X, Xenorhabdus 278 DNA digested with EcoRI (see Fig. 2 legend).

main conserved groups of ribotypes. Strikingly, strains of ribotypes R2 and R3 belonged to pulsotype subgroup I, and those of ribotype R4 to subgroup II (Table 2). Therefore, and in contrast to REAP, the two techniques analysing chromosomal polymorphisms led to the same subgrouping scheme. These results confirm the previous observation that the $2 / 09 / \mathrm{X}_{3}$ strains of $Y$. enterocolitica form two subgroups: I (pulsotype I, ribotypes R2 and R3) and II (pulsotype II, ribotype $\mathrm{R} 4$ ).

\section{Subdivision of $2 / 05$ strains of $Y$. enterocolitica into a homogeneous group and 1A/O5 strains into a heterogeneous group}

Y. enterocolitica strains of serotype $\mathrm{O} 5$ are biochemically heterogeneous, belonging either to biotype $1 \mathrm{~A}$ (non-pathogenic environmental isolates) or to pathogenicity-associated biotypes 2 or 3 [21]. 1A/O5 strains of $Y$. enterocolitica have also been clearly differentiated from the $2 / 05$ strains (previously called 3/O5) by PFGE [6].

In the present study, the REAP technique could not be applied to 1A/O5 strains because, as expected, none harboured a virulence plasmid. Ribotyping of these strains identified two EcoRI (d and e) and three EcoRV (e-g) hybridisation profiles that were specific for the 1A/O5 group of strains (Fig. 2 and Table 2). Therefore, three ribotypes (R5-R7) were found among the 16 strains studied, indicating a limited degree of heterogeneity amongst the 1A/O5 strains. A high degree of polymorphism in PFGE genomic restriction profiles (14 pulsotypes for 16 strains) was also noted among these strains [6].

In contrast, three of the four 2/O5 strains studied harboured a pYV plasmid and displayed the same REAP pattern (P4; Table 3). This pattern corresponds to the REAP pattern II described by Nesbakken et al. [13] and Fukushima et al. [22]. These authors described two additional REAP patterns that were not observed amongst our strains. This discrepancy may be explained by the different geographical origin of the isolates, in that strains with REAP pattern I were isolated in Japan and those with REAP pattern III in Japan and the USA [22]. Although the 2/O5 strains had a specific EcoRI profile (Fig. 1), their Bam HI profile was identical to that of $4 / \mathrm{O} 3$ strains.

Similarly, all the $2 / 05$ strains studied had the same specific ribotype (R8; Table 3), but their EcoRI ribopattern was identical to that of the $4 / \mathrm{O} 3$ strains. Their EcoRV ribopattern, although different, shared several bands with the 4/O3 strains (Fig. 2). Therefore, REAP and ribotyping both indicate that the 4/O3 and $2 / 05$ strains are genetically closer to each other than to the 2/O9 strains. The two techniques also indicated that the 2/O5 $Y$. enterocolitica strains tested were homogeneous. Although four different pulsotypes were observed among these four strains, their Not I genomic patterns also had sufficient similarities to group them [6]. Therefore, the four $2 / 05$ isolates tested formed a homogeneous group of strains.

\section{Specific characteristics of 3/O3 strains of $Y$. enterocolitica}

Analysis of the plasmid restriction profiles of three $Y$. enterocolitica strains with an uncommon phenotypebiotype 3 and serotype $\mathrm{O} 3(3 / \mathrm{O} 3)$-revealed that two of these strains differed from other pathogenic $Y$. enterocolitica strains by the carriage of additional plasmids (Table 4).

Strain IP 22227 harboured a small plasmid (pX) that, after digestion with Not I, migrated as a single $c .5-\mathrm{kb}$ 
Table 2. Characteristics of $2 / 09 / \mathrm{X}_{3}$ strains of $Y$. enterocolitica

\begin{tabular}{|c|c|c|c|c|c|c|}
\hline $\begin{array}{l}\text { Strain } \\
\text { no. }\end{array}$ & Origin & Source & $\begin{array}{l}\text { Country } \\
\text { of origin }\end{array}$ & Pulsotype* & $\begin{array}{l}\operatorname{REAP}^{\dagger} \\
(\text { EcoRI/Bam HI })\end{array}$ & $\begin{array}{l}\text { Ribotype }^{\ddagger} \\
(E c o R I / E c o R V)\end{array}$ \\
\hline IP 19917 & Food & Pork meat & Argentina & $\left.2^{\mathrm{A}}\right]$ & $\xi$ & $\mathrm{R} 2(\mathrm{~b} / \mathrm{b})$ \\
\hline IP 22370 & Food & Ham & Argentina & $2^{\mathrm{A}}$ & $\xi$ & $\mathrm{R} 2(\mathrm{~b} / \mathrm{b})$ \\
\hline IP 22373 & Food & Pork meat & Argentina & $2^{\mathrm{A}}$ & $\xi$ & $\mathrm{R} 2(\mathrm{~b} / \mathrm{b})$ \\
\hline IP 22374 & Food & Salami & Argentina & $2^{\mathrm{A}}$ & $\xi$ & $\mathrm{R} 2(\mathrm{~b} / \mathrm{b})$ \\
\hline IP 22352 & Food & Meat & Argentina & $2^{\mathrm{A}}$ & $\vec{\xi}$ & $\mathrm{R} 2(\mathrm{~b} / \mathrm{b})$ \\
\hline IP 383 & Man & Stool & Belgium & $2^{\mathrm{B}}$ & P2 $(2 / 2)$ & $\mathrm{R} 2(\mathrm{~b} / \mathrm{b})$ \\
\hline IP 19262 & Man & Stool & Turkey & $2^{C}$ & $\xi$ & $\mathrm{R} 2(\mathrm{~b} / \mathrm{b})$ \\
\hline IP 21251 & Man & Stool & France & $2^{\mathrm{D}}$ & P2 $(2 / 2)$ & $\mathrm{R} 2(\mathrm{~b} / \mathrm{b})$ \\
\hline IP 21349 & Man & $\mathrm{UN}$ & France & $2^{\mathrm{D}}$ & P3 $(3 / 3)$ & $\mathrm{R} 2(\mathrm{~b} / \mathrm{b})$ \\
\hline IP 22349 & Food & Pork meat & Argentina & $2^{\mathrm{E}}$ & $\xi$ & $\mathrm{R} 2(\mathrm{~b} / \mathrm{b})$ \\
\hline IP 21404 & Food & Egg & Argentina & $2^{F}$ & $\mathrm{P} 2(2 / 2)$ & $\mathrm{R} 2(\mathrm{~b} / \mathrm{b})$ \\
\hline IP 20188 & Man & UN & Holland & $2^{\mathrm{G}}$ & P2 $(2 / 2)$ & $\mathrm{R} 2(\mathrm{~b} / \mathrm{b})$ \\
\hline IP 23073 & Man & Aneurysm & France & $2^{\mathrm{G}}$ & P3 $(3 / 3)$ & $\mathrm{R} 2(\mathrm{~b} / \mathrm{b})$ \\
\hline IP 21194 & Man & Blood & Switzerland & $2^{\mathrm{H}}$ & P2 $(2 / 2)$ & $\mathrm{R} 2(\mathrm{~b} / \mathrm{b})$ \\
\hline IP 20754 & Man & Stool & Switzerland & $2^{I}$ & $\mathrm{P} 2(2 / 2)$ & R3 (b/d) \\
\hline IP 20851 & Man & Stool & Spain & $2^{J}$ & $\xi$ & $\mathrm{R} 2(\mathrm{~b} / \mathrm{b})$ \\
\hline IP 23128 & Bovine & Stool & France & $\left.2^{\mathrm{K}}\right]$ & P3 $(3 / 3)$ & $\mathrm{R} 4(\mathrm{c} / \mathrm{c})$ \\
\hline IP 21447 & Pig & Stool & Great Britain & $2^{\mathrm{K}}$ & P3 $(3 / 3)$ & $\mathrm{R} 4(\mathrm{c} / \mathrm{c})$ \\
\hline IP 23038 & Man & Stool & France & $2^{\mathrm{K}}$ & P3 $(3 / 3)$ & $\mathrm{R} 4(\mathrm{c} / \mathrm{c})$ \\
\hline IP 23039 & Man & Blood & France & $2^{\mathrm{L}}$ & $\xi$ & $\mathrm{R} 4(\mathrm{c} / \mathrm{c})$ \\
\hline
\end{tabular}

See footnotes to Table 1 .

Table 3. Characteristics of serotype $\mathrm{O} 5$ strains of $Y$. enterocolitica

\begin{tabular}{|c|c|c|c|c|c|c|c|c|}
\hline $\begin{array}{l}\text { Strain } \\
\text { no. }\end{array}$ & Biotype & $\begin{array}{l}\text { Phage } \\
\text { type }\end{array}$ & Origin & Source & $\begin{array}{l}\text { Country } \\
\text { of origin }\end{array}$ & Pulsotype* & $\begin{array}{l}\operatorname{REAP}^{\dagger} \\
(E c o R I / B a m \mathrm{HI})\end{array}$ & $\begin{array}{l}\text { Ribotype }^{\ddagger} \\
(E c o \text { RI } / E c o \text { RV })\end{array}$ \\
\hline IP 21398 & $1 \mathrm{~A}$ & Xo & Goat & UN & Argentina & $1 \mathrm{~A}^{\mathrm{A}}$ & $\xi$ & $\mathrm{R} 5(\mathrm{~d} / \mathrm{e})$ \\
\hline IP 22345 & $1 \mathrm{~A}$ & Xo & Food & Chicken & Argentina & $1 \mathrm{~A}^{\mathrm{A}}$ & $\xi$ & R5 (d/e) \\
\hline IP 22376 & $1 \mathrm{~A}$ & $\mathrm{Xz}$ & Bovine & Tongue & Argentina & $1 \mathrm{~A}^{\mathrm{A}}$ & $\xi$ & R5 (d/e) \\
\hline IP 21160 & $1 \mathrm{~A}$ & $\mathrm{Xz}$ & Environment & UN & Greece & $1 A^{B}$ & $\xi$ & $\mathrm{R} 5(\mathrm{~d} / \mathrm{e})$ \\
\hline IP 20952 & $1 \mathrm{~A}$ & $\mathrm{Xz}$ & Man & Stool & Switzerland & $1 \mathrm{~A}^{C}$ & $\vec{\xi}$ & R5 (d/e) \\
\hline IP 22661 & $1 \mathrm{~A}$ & Xo & Pig & Caecum & Argentina & $1 \mathrm{~A}^{\mathrm{D}}$ & $\xi$ & R5 (d/e) \\
\hline IP 21385 & $1 \mathrm{~A}$ & $\mathrm{Xz}$ & Food & Fish & France & $1 A^{E}$ & $\xi$ & R5 (d/e) \\
\hline IP 20721 & $1 \mathrm{~A}$ & $\mathrm{Xz}$ & Food & Milk & France & $1 A^{F}$ & $\xi$ & R5 (d/e) \\
\hline IP 23040 & $1 \mathrm{~A}$ & $X z$ & Man & Stool & France & $1 \mathrm{~A}^{\mathrm{G}}$ & $\xi$ & R5 (d/e) \\
\hline IP 20351 & $1 \mathrm{~A}$ & $\mathrm{Xz}$ & Man & Stool & France & $1 \mathrm{~A}^{\mathrm{H}}$ & $\xi$ & R6 (e/f) \\
\hline IP 21370 & $1 \mathrm{~A}$ & $\mathrm{Xz}$ & Food & Poultry & France & $1 \mathrm{~A}^{\mathrm{l}}$ & $\xi$ & $\mathrm{R} 5(\mathrm{~d} / \mathrm{e})$ \\
\hline IP 22783 & $1 \mathrm{~A}$ & $X z$ & Man & Appendix & Italy & $1 \mathrm{~A}^{\mathrm{J}}$ & $\xi$ & R6 (e/f) \\
\hline IP 22260 & $1 \mathrm{~A}$ & $\mathrm{Xz}$ & Food & Egg & France & $1 \mathrm{~A}^{\mathrm{K}}$ & $\vec{\xi}$ & R6 (e/f) \\
\hline IP 21110 & $1 \mathrm{~A}$ & Xo & Food & Cheese & Spain & $1 A^{L}$ & $\xi$ & R6 (e/f) \\
\hline IP 21131 & $1 \mathrm{~A}$ & Xo & Food & Cream & Spain & $1 \mathrm{~A}^{\mathrm{M}}$ & $\xi$ & R7 (d/g) \\
\hline IP 21363 & $1 \mathrm{~A}$ & $\mathrm{Xz}$ & Food & Carrot & France & $1 \mathrm{~A}^{\mathrm{N}}$ & $\xi$ & $\mathrm{R} 5(\mathrm{~d} / \mathrm{e})$ \\
\hline IP 22464 & 2 & $X z$ & Man & UN & Australia & $2^{\mathrm{O}}$ & P4 (4/1) & $\mathrm{R} 8(\mathrm{a} / \mathrm{h})$ \\
\hline IP 22981 & 2 & $\mathrm{Xz}$ & Man & Blood & France & $2^{P}$ & P4 (4/1) & $\mathrm{R} 8(\mathrm{a} / \mathrm{h})$ \\
\hline IP 21100 & 2 & $\mathrm{Xz}$ & Man & Blood & France & $2^{Q}$ & $\xi$ & $\mathrm{R} 8(\mathrm{a} / \mathrm{h})$ \\
\hline IP 885 & 2 & $X z$ & Dog & Stool & Great Britain & $2^{\mathrm{K}}$ & P4 (4/1) & $\mathrm{R} 8(\mathrm{a} / \mathrm{h})$ \\
\hline
\end{tabular}

See footnotes to Table 1 .

Table 4. Characteristics of $3 / \mathrm{O} 3 / \mathrm{Xz}$ strains of $Y$. enterocolitica

\begin{tabular}{|c|c|c|c|c|c|}
\hline $\begin{array}{l}\text { Strain } \\
\text { no. }\end{array}$ & Origin & $\begin{array}{l}\text { Country } \\
\text { of origin }\end{array}$ & Pulsotype* & $\begin{array}{l}\mathrm{REAP}^{\dagger} \\
(\text { EcoRI/Bam } \mathrm{HI})\end{array}$ & $\begin{array}{l}\text { Ribotype }{ }^{\ddagger} \\
(E c o \mathrm{RI} / E c o \mathrm{RV})\end{array}$ \\
\hline IP 22227 & Ovine & Australia & $3^{\mathrm{A}}$ & P5 $(5 / 3)+p X$ & R9 (f/i) \\
\hline IP 23438 & Dog & Spain & $3^{\mathrm{B}}$ & P4 (4/1) & $\mathrm{R} 10(\mathrm{~g} / \mathrm{j})$ \\
\hline IP 23446 & Dog & Spain & $3^{\mathrm{B}}$ & $P 4(4 / 1)+p Y$ & $\mathrm{R} 10(\mathrm{~g} / \mathrm{j})$ \\
\hline
\end{tabular}

See footnotes to Table 1. $\mathrm{pX}$ and $\mathrm{pY}$ indicate the presence of additional uncharacterised plasmids.

band (data not shown). When the additional restriction fragments associated with the presence of $\mathrm{pX}$ were ignored, strain IP 22227 had a specific EcoRI restriction pattern, but a $B a m$ HI pattern identical to that of the 2/O9 strains (Fig. 1 and Table 4). Strain IP 22227 also had unique EcoRI and Eco RV ribopatterns
(Fig. 4), but these profiles were virtually identical to those of group I 2/O9 strains. Therefore, both ribotyping and REAP suggest that strain IP 22227 had most likely diverged from the 2/O9 group of strains. The PFGE profile of this strain was compared previously with biotype 3 and 4 strains [6] and shared 
more similarities with the former. However, the pulsotype of this strain was not compared previously with the group I $2 / 09$ strains.

Strain IP 23446 also carried an additional plasmid (pY) which, in its uncut form, migrated as a large band of $>30 \mathrm{~kb}$ (data not shown). This plasmid generated additional small EcoRI restriction fragments and larger Bam HI fragments (Fig. 1). However, when the extra bands were ignored, the EcoRI and Bam HI plasmid restriction profiles of strain IP 23446 corresponded to REAP pattern P4 as found with 2/ O5 strains (Fig. 1 and Table 4). Similarly, strain IP 23438, which did not carry an additional plasmid, but exhibited a pulsotype identical to that of the other 3/ O3 strain from Spain, also had REAP pattern P4 (Table 4). These results contrast with those of Kapperud et al. [14] and Kaneko and Maruyama [23] who did not report any extra plasmids in the 3/ O3 strains studied and found that the EcoRI restriction profiles were identical to those of $4 / \mathrm{O} 3$ isolates. However, the strains studied previously were isolated only in Japan, whereas those in the present study came from other countries. Therefore, it is possible that different $3 / \mathrm{O} 3$ clones have spread in different geographical areas.

Analysis of the ribotypes of strains IP 23438 and IP 23446 demonstrated that the two strains had identical hybridisation profiles. Their EcoRI ribopattern was very close to that of the $4 / \mathrm{O} 3$ and $2 / \mathrm{O} 5$ strains (Fig.
4A), but they had a unique $E c o$ RV profile (j) which was nonetheless very close to the EcoRV ribopattern (h) of the 2/O5 strains (Fig. 4B). Therefore, the two 3/ $\mathrm{O} 3$ isolates from Spain were linked closely to the $2 /$ O5 strains of $Y$. enterocolitica. In contrast, Andersen and Saunders [16] found that the Nci I and AvaI ribopatterns of $3 / \mathrm{O} 3$ strains were identical to those of $4 / \mathrm{O} 3$ strains. The $3 / \mathrm{O} 3$ strains used by these authors were isolated in Japan and were of phage type II. Japanese 3/O3/II strains studied by multilocus enzyme electrophoresis (MLEE) [20] were also identical to 4/ O3 strains. Therefore, the results of ribotyping, REAP and MLEE suggest that the $3 / \mathrm{O} 3$ strains from Japan may correspond to the emergence of a particular clone derived from a $4 / \mathrm{O} 3$ parental strain. In contrast, the three $3 / \mathrm{O} 3 / \mathrm{Xz}$ strains from the present study are of differential geographical origins and phage type. One of these three strains (IP 22227) may have derived from a 2/O9 clone, and the two others from a $2 / 05$ clone.

\section{Relatedness of the different bioserotypes of $Y$. enterocolitica}

Based on the results of ribotyping, phenotypic markers, REAP and PFGE, the strains analysed in this study could be grouped into three clusters.

The first cluster comprised the non-pathogenic 1A/O5 strains that displayed a relative heterogeneity of their ribotypes and pulsotypes. Three ribotypes and 12
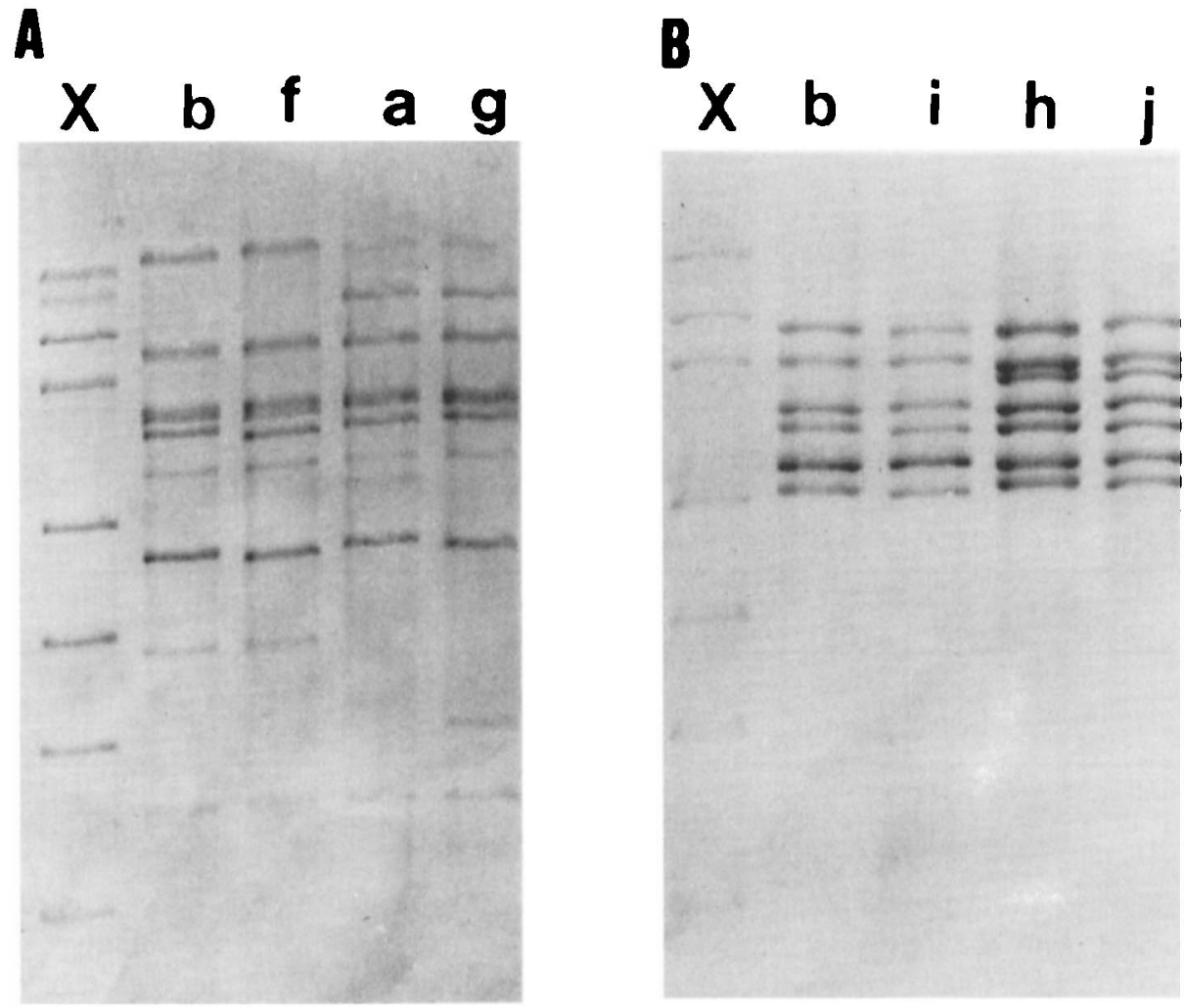

Fig. 4. Comparison of: A, EcoRI; B, EcoRV ribopatterns found amongst 3/O3/Xz strains of $Y$. enterocolitica with the most similar patterns from other strains. Track letters correspond to the different ribopatterns listed in the Tables. $\mathbf{X}$, Xenorhabdus 278 DNA digested with EcoRI (see Fig. 2 legend). 
pulsotypes were identified among the 16 strains studied. Dolina and Peduzzi [24] showed with MLEE that the 1/O5 strains belonged to a group that included all strains of biotype 1 and differed from a second group comprising pathogenic strains of biotypes 2,3 and 4. In the present study, the overall EcoRI and EcoRV ribopatterns of $1 \mathrm{~A} / \mathrm{O} 5$ strains were more similar to each other than to the ribopatterns of pathogenic strains (Fig. 2).

The second cluster included all the $2 / 09$ strains, plus the 3/O3 strain IP 22227, which shared different but very close EcoRI and EcoRV ribopatterns and an identical Bam HI REAP pattern.

The third cluster contained all the 4/O3 and 2/O5 strains and the two 3/O3 strains from Spain (IP 23438 and IP 23446). These strains shared identical or very close EcoRI ribopatterns and an identical Bam HI REAP pattern 1 (Tables 1,3 and 4). Within this cluster, the $2 / \mathrm{O} 5$ and $3 / \mathrm{O} 3$ strains were more similar to each other than to the $4 / \mathrm{O} 3$ group as they had very close EcoRI REAP profiles and EcoRV ribopatterns. Caugant et al. [20] used MLEE to show that strains of bioserotypes $3 / \mathrm{O} 3,4 / \mathrm{O} 3$ and $2 / \mathrm{O} 5,27$ were genetically linked more closely to each other than to the $2 / 09$ group of strains, but were unable to differentiate $3 / \mathrm{O} 3$ strains from $4 / \mathrm{O} 3$ strains.

Despite the existence of different pYV plasmid restriction profiles, all pathogenic strains tested had at least four Bam HI fragments of identical molecular sizes (Fig. 1). Similarly, bands of identical molecular sizes were present in both the EcoRI and EcoRV ribopatterns of the 63 strains of $Y$. enterocolitica studied (Fig. 2), but when the ribopatterns of these isolates were compared with those of $Y$. pestis obtained previously with the same probe and restriction endonucleases [8], no similarities were found (data not shown). Further work will be necessary to determine whether the apparently conserved plasmid or chromosomal bands in $Y$. enterocolitica are species specific.

\section{Comparison of the ability of REAP, ribotyping} and PFGE to type and subtype pathogenic strains of $Y$. enterocolitica

Since the differentiation of $Y$. enterocolitica biotypes, or even species of Yersinia, is based sometimes on a limited number of biochemical tests, an atypical reaction may lead to erroneous identication of the strain. In such cases the use of molecular typing methods may be a useful alternative to classical phenotypic methods. Of the three molecular techniques examined, REAP was the simplest and fastest to perform. However, this technique is not suitable for non-pathogenic strains (e.g., those of biotype 1A), potentially virulent strains that have lost their $\mathrm{pYV}$ plasmid and strains harbouring extra plasmids. Among the 26 pYV-harbouring strains studied, the REAP pattern was specific for almost each bioserotype: PI for 4/O3; $\mathrm{P} 2$ and $\mathrm{P} 3$ for $2 / \mathrm{O} 9$; $\mathrm{P} 4$ for $3 / \mathrm{O} 3$ and $2 / \mathrm{O} 5$; and P5 for $3 / \mathrm{O} 3$ (see Tables 1-4). Therefore, with the exception of $3 / \mathrm{O} 3$ and $2 / \mathrm{O} 5$ strains, REAP was a useful typing tool. Bam $\mathrm{HI}$ was less discriminatory than EcoRI as digestion with EcoRI alone was sufficient to distinguish most of the bioserotypes. Within a given bioserotype, the diversity of the REAP patterns was either very limited or nil. Only five REAP patterns were observed among the 26 pYV-harbouring strains, indicating that REAP is not a suitable method for subtyping $Y$. enterocolitica isolates.

Ribotyping is more time-consuming than REAP, since an additional step of DNA transfer and hybridisation is necessary, but no sophisticated equipment is required. One advantage of ribotyping over REAP is that it can be applied to all strains of $Y$. enterocolitica, as well as to other Yersinia spp. A close relationship was found between the ribotypes and bioserotypes of the strains: 4/O3 with $\mathrm{R} 1 ; 2 / \mathrm{O} 9$ with $\mathrm{R} 2-4$; 1A/O5 with R5-7; 2/O5 with R8; and 3/O3 with R9 and R10. Therefore, ribotyping differentiated the bioserotypes clearly and was a more discriminatory typing tool than REAP. EcoRI was not the most appropriate endonuclease for this purpose since both 4/O3 and 2/O5 isolates had the same EcoRI ribopattern. In contrast, digestion with $E c o$ RV alone was sufficient to differentiate the bioserotypes. Ribotyping was also more effective than REAP in subdividing strains of the same bioserotype. Ten different ribotypes were observed among the strains studied. However, this diversity is still too low to consider ribotyping as a powerful tool for studying the epidemiology of $Y$. enterocolitica infection.

PFGE requires more sophisticated and expensive equipment. With this technique, pathogenic strains of $Y$. enterocolitica have been grouped efficiently into their different bioserotypes, based on their overall genomic profiles $[6,25,26]$. However, because of the large number of restriction fragments $(>40)$ and profiles observed, the pulsotypes are more difficult to compare than ribotypes or plasmid profiles. Therefore, PFGE is not the most convenient typing method for Yersinia strains but, in contrast to ribotyping and REAP, PFGE allows efficient subtyping of strains. This is especially true for the most widespread strains of bioserotype 4/O3, which all displayed the same REAP pattern and ribotype but could be subdivided into 11 pulsotypes. Other workers [26] have also found that PFGE typing is more efficient than MLEE for epidemiological analysis of yersiniosis. The only exceptions found were two pairs of $2 / 09$ strains that displayed identical pulsotypes but different REAP patterns. Otherwise, PFGE allowed subdivision of the 63 strains studied into 43 pulsotypes, while only five REAP patterns and 10 ribotypes were identified. 
An interesting feature of this study was that the two techniques that analysed chromosomal polymorphisms (ribotyping and PFGE) resulted in the same subtyping scheme for the 2/O9 strains, while the REAP plasmid profiles gave a completely different subtyping scheme. Some strains that had the same ribotype and pulsotype yielded two different REAP patterns, while some strains with identical REAP patterns had different ribotypes and pulsotypes (Table 2). This indicates that classifications and dendrograms based on plasmid and chromosomal markers will lead to different conclusions about the evolution of $Y$. enterocolitica strains.

\section{Conclusions}

By comparing the three techniques it appears that $Y$. enterocolitica strains can be subdivided into different bioserotypes by REAP (with EcoRI) or, more efficiently, by ribotyping (with EcoRV), although it is simpler, faster and cheaper to use the classical phenotypic markers on a routine basis. However, REAP and ribotyping are valuable alternatives for characterising autoagglutinating Yersinia strains or those exhibiting atypical biochemical reactions. Atypical biochemical reactions are not rare among Yersinia spp. and can make bacteriological identification difficult. Since the pathogenicity of a strain, and therefore the treatment of patients, depends upon the species and the biotype of the infecting isolate, it is crucial to have alternative identification tests available. REAP and ribotyping are valuable methods, but the low degree of polymorphism seen in the REAP patterns, and to a lesser extent in the ribopatterns, within strains of the same bioserotype limits their suitability for epidemiological tracing. In comparison, PFGE requires sophisticated equipment, and the complexity of the pulsotypes means that PFGE is not the most convenient tool for Yersinia typing. However, for epidemiological studies, PFGE is more effective than ribotyping or REAP and is probably one of the most powerful tools available.

We thank I. Old and Carmen Buchrieser for their critical reading of the manuscript. The advice of G. Wauters for the preparation of the new indole medium was highly valuable. I. I. received a scholarship from the French Ministry of Research and Technology.

\section{References}

1. Wauters G, Kandolo K, Janssens M. Revised biogrouping scheme of Yersinia enterocolitica. In: Prpic JK, Davey RB (eds) The genus Yersinia: epidemiology, molecular biology and pathogenesis. Contrib Microbiol Immunol 1987; 9: 14-21.

2. Fukushima, H. Isolation of Yersinia enterocolitica serogroup O:8, biogroup-1B-Reply. J Clin Microbiol 1991; 29: 2680.

3. Wauters G, Aleksic S, Charlier J, Schulze G. Somatic and flagellar antigens of Yersinia enterocolitica and related species. Contrib Microbiol Immunol 1991; 12: 239-243.

4. Nicolle P, Mollaret HH, Brault J. La lysotypie de Yersinia enterocolitica. Arguments géographiques, zoologiques, antigéniques et biochimiques plaidant en sa faveur. Bull Acad Natl Med 1976; 160: 404-408.
5. Aleksic S, Bockemühl J, Lange F. Studies on the serology of flagellar antigens of Yersinia enterocolitica and related Yersinia species. Zentralbl Bakteriol Mikrobiol Hyg A 1986; 261: 299310.

6. Najdenski H, Iteman I, Carniel E. Efficient subtyping of pathogenic Yersinia enterocolitica strains by pulsed-field gel electrophoresis. J Clin Microbiol 1994; 32: 2913-2920.

7. Birnboim HC, Doly J. A rapid alkaline extraction procedure for screening recombinant plasmid DNA. Nucleic Acids Res 1979; 7: 1513-1523

8. Guiyoule A, Grimont F, Iteman I, Grimont PAD, Lefèvre M, Carniel E. Plague pandemics investigated by ribotyping of Yersinia pestis strains. J Clin Microbiol 1994; 32: 634-641.

9. Grimont F, Lèfevre M, Ageron E, Grimont PAD. rRNA gene restriction patterns of Legionella species: a molecular identification system. Res Microbiol 1989; 140: 615-626.

10. Portnoy DA, Moseley SL, Falkow S. Characterization of plasmids and plasmid-associated determinants of Yersinia enterocolitica pathogenesis. Infect Immun 1981; 31: 775-782.

11. Heesemann J, Keller C, Morawa R, Schmidt N, Siemens HJ, Laufs R. Plasmids of human strains of Yersinia enterocolitica: molecular relatedness and possible importance for pathogenesis. $J$ Infect Dis 1983; 147: 107-115.

12. Kapperud G, Nesbakken T. Restriction endonuclease analysis of 40- to 50-Mdalton plasmids from Yersinia enterocolitica strains of worldwide origin. Contrib Microbiol Immunol 1987; 9: $317-323$.

13. Nesbakken T, Kapperud G, Sørum H, Dommarsnes $\mathrm{K}$. Structural variability of $40-50 \mathrm{Mdal}$ virulence plasmids from Yersinia enterocolitica. Geographical and ecological distribution of plasmid variants. APMIS 1987; 95: 167-173.

14. Kapperud G, Nesbakken T, Aleksic S, Mollaret HH. Comparison of restriction endonuclease analysis and phenotypic typing methods for differentiation of Yersinia enterocolitica isolates. $J$ Clin Microbiol 1990; 28: 1125-1131.

15. Picard-Pasquier N, Picard B, Heeralal S, Krishnamoorthy R, Goullet P. Correlation between ribosomal DNA polymorphism and electrophoretic enzyme polymorphism in Yersinia. J Gen Microbiol 1990; 136: 1655-1666.

16. Andersen JK, Saunders NA. Epidemiological typing of Yersinia enterocolitica by analysis of restriction fragment length polymorphisms with a cloned ribosomal RNA gene. J Med Microbiol 1990; 32: 179-187.

17. Blumberg HM, Kiehlbauch JA, Wachsmuth IK. Molecular epidemiology of Yersinia enterocolitica $0: 3$ infections: use of chromosomal DNA restriction fragment length polymorphisms of rRNA genes. J Clin Microbiol 1991; 29: 2368-2374.

18. Mollaret HH, Bercovier H, Alonso JM. Yersinia. In: Le Minor $L$, Véron $M$ (eds) Bactériologie médicale. Paris, Flammarion. 1989: 451-472.

19. Pham JN, Bell SM, Hardy MJ, Martin L, Guiyoule A, Carniel E. Susceptibility to $\beta$-lactam agents of Yersinia enterocolitica biotype 4, serotype $\mathrm{O} 3$ isolated in various parts of the world. J Med Microbiol 1995; 43: 9-13.

20. Caugant DA, Aleksic S, Mollaret HH, Selander RK, Kapperud G. Clonal diversity and relationships among strains of Yersinia enterocolitica. J Clin Microbiol 1989; 27: 2678-2683.

21. Cornelis G, Laroche Y, Balligand G, Sory M-P, Wauters G. Yersinia enterocolitica, a primary model for bacterial invasiveness. Rev Infect Dis 1987; 9: 64-87.

22. Fukushima H, Gomyoda $M$, Aleksic S, Tsubokura M. Differentiation of Yersinia enterocolitica serotype O:5,27 strains by phenotypic and molecular techniques. $J$ Clin Microbiol 1993; 31: 1672-1674.

23. Kaneko S, Maruyama T. Pathogenicity of Yersinia enterocolitica serotype O3 biotype 3 strains. J Clin Microbiol 1987; 25: $454-455$.

24. Dolina M, Peduzzi R. Population genetics of human, animal, and environmental Yersinia strains. Appl Environ Microbiol 1993; 59: 442-450.

25. Buchrieser C, Weagant SD, Kaspar CW. Molecular characterization of Yersinia enterocolitica by pulsed-field gel electrophoresis and hybridization of DNA fragments to ail and pYV probes. Appl Environ Microbiol 1994; 60: 4371-4379.

26. Saken E, Roggenkamp A, Aleksic S, Heesemann J. Characterisation of pathogenic Yersinia enterocolitica serogroups by pulsed-field gel electrophoresis of genomic Not I restriction fragments. J Med Microbiol 1994; 41: 329-338. 